\title{
Study on Impact Parameters of Rigidity and Flexibility for Buried Corrugated Steel Culvert
}

\author{
Baodong Liu*, Zongmin Liu, Miaoxin Zhang and Quanlu Wang
}

School of Civil Engineering, Beijing Jiaotong University, Beijing 100044, China

\begin{abstract}
Buried corrugated steel culverts are universally regarded as a structure with strong deformation adaptability and dispersed the upper load by corrugated steel structures surrounding soil constraints to enhance the carrying capacity and the use of soil-structure interaction. A lot of factors influence the earth pressure of the buried corrugated steel culvert, such as culvert stiffness, physical characteristics of the backfill (bulk density, deformation modulus and internal friction angle), geometry of structure and backfilling height. The finite element program of ANSYS has been used to research the elastic modulus, Poisson's ratio, internal friction angle of soil, inertia moment of corrugated steel plate and pipe diameter affect the rigidity and flexibility of buried corrugated steel culvert. By defining path lines in the finite element post-processing, extracting and comparing the horizontal and vertical directions soil displacements along the lines, and doing impact parameter analysis. Classification for flexible and rigid pipes of the buried corrugated steel pipe culvert structure has been made according to the analysis results. A theoretical reference has been provided for the design and construction of the buried corrugated steel pipe culverts.
\end{abstract}

Keywords: Buried corrugated steel culvert, rigidity and flexibility, soil displacement, finite element analysis.

\section{INTRODUCTION}

Buried corrugated steel pipe culvert is a typical soilstructure interaction structure, backfill is both load and load receptor, structure and surrounding soil are working together to cause the earth pressure re-distribution. Meanwhile the earth pressure effect on the structure again and makes a better deformation and mechanical properties of the structural system. However, when the structural stiffness changed, deformation and stress have a big difference, especially for buried corrugated steel culvert [1]. When the relative settlement of the soil prism directly above the structure is less than that of the adjacent soil prisms, the earth load on the pipe is increased by the amount of the downward shearing forces exerted on the central soil prism, the pipe which is referred to as rigidity pipe. Likewise, when the relative settlement of the soil prism directly above the structure is greater than that of the adjacent soil prisms, the layers of soil in the central prism are subjected to a reverse arch shape deformation and consequently the earth load on the pipe is reduced by the upward shearing forces exerted on the central soil prism, the pipe which is referred to as flexibility pipe.

Studying of such structure is still at the starting stage in China, and also immature of rigid and flexible property in the world. The American Railway Engineering Association did experiment at the Illinois Central Railroad, the first time proving buried corrugated steel plate structure exist significant soil-steel interaction. The earth pressure test results

*Address correspondence to this author at the School of Civil Engineering, Beijing Jiaotong University, Beijing 100044, China; Tel:+86-10-51687252: Fax:+86-10-51687248; E-mail:baodongliu@vip.sina.com showed that flexible pipe structure only bear its $60 \%$ of the soil column load, the remaining $40 \%$ beard by the surrounding soil [2]. Junsuk Kang investigated the strengths of buried corrugated steel pipes, one conclusion was the earth pressure distribution and soil arching for rigid pipes and flexible pipes were slightly different [3]. Susan A. trickey investigated three-dimensional response of buried pipes under circular surface loading using the finite-element method. Analyses were performed for pipes of varying stiffness and embedment depths. When stiff pipes were located close to the ground surface, the burial depth had little impact on the peak deflection. However, flexible pipe deflections decrease significantly as embedment depth increases. Peak moment increase with pipe stiffness and decrease as the pipes became more remote from the ground surface [4]. Field performance and tests showed that pipe of different relative stiffness coefficient, the vertical earth pressure values and the distribution of earth pressure were different [5]. As can be seen in references 2,3,4,5 the force conditions of rigidity and flexibility for buried corrugated steel culvert have a great difference. According to the force and deformation of the pipe culverts in China "Guidelines for Design of Highway Culvert", concrete culvert was divided into flexible pipe and rigid pipe, and a distinction formula was given [6]. Buried pipe was divided into rigid pipe and flexible pipe, and respectively calculated the earth pressure of different pipe in "Structural design code for pipelines of water supply and waste water engineering" [7]. American scholar Ian D. Moore did further study of the buried culvert structure, $\mathrm{He}$ believed that the performance of the pipe was largely affected by different locations backfill. Relative stiffness was influenced by two different types of pipe and soil deformation: 
bending and hoop compression. Pipe rigidity or flexibility can been defined using relative stiffness parameters $\mathrm{C}$ and $\mathrm{F}$. Pipe stiffness categories were: Rigid, Semi-flexible, Flexible and Compressible [8]. As can be seen in references 6, 7, 8 at some bridge design specifications have distinction formula about rigidity and flexibility, but not for corrugated steel culvert.

In this paper, the finite element method has been used to analyze the rigid and flexible property of buried corrugated pipe culvert. And a distinction formula of rigid pipe and flexible pipe is given for buried corrugated steel pipe culverts, which provide a theoretical reference for the design and construction of the buried corrugated steel pipe culverts.

\section{Finite Element Analysis Models}

Assuming corrugated pipe culvert is long enough in the longitudinal direction, it is feasible to treat the pipe of one unit length as plane-strain problem and to be calculated using 2-D model. When creating the model, based on the equivalent stiffness principle corrugated steel plate can be simplified as flat plate [9]. Beam 3 elements is utilized for corrugated steel plate unit, plane 82 element is adopted for the soil unit; add the contact element and introduce coupled nodes for structure-soil interaction. The profile of the corrugated steel plate is initially defined as $150 * 55 * 5 \mathrm{~mm}$. The elastic modulus and density of the steel plate are $2 \times 10^{5} \mathrm{MPa}$ and $7850 \mathrm{~kg} / \mathrm{m}^{3}$. The elastic modulus, density, Poisson's ratio and internal friction angles of the soil are initially assumed as $15 \mathrm{MPa}, 1900 \mathrm{~kg} / \mathrm{m}^{3}, 0.3$ and $30^{\circ}$. The pipe culvert diameter is initially defined as $3 \mathrm{~m}$ and the depth of soil cover is $3 \mathrm{~m}$.

In order to compare the soil deformation in specified location, three path lines are defined. The vertical path NO.1 is from the pipe top to backfill surface, the vertical path NO. 2 is the NO.1 offset to the right side of $1.5 \mathrm{~m}$, the horizontal path is a horizontal line on the pipe top. The finite element analysis model is shown in Fig. (1).

\section{Impact Parameter Analysis}

Selecting the factors affecting the soil-structure interaction such as: soil elastic modulus, soil Poisson's ratio, soil internal friction angle, pipe culvert diameter and pipe culvert cross section moment of inertia, to do the finite element analysis in detail. By extracting the displacement along the path line, the factors affect the mechanical of the structure and the degree of the influence can be conducted.

\section{SOIL ELASTIC MODULUS}

The backfill should be carried out symmetrically during the period of construction and ensure have enough compaction degrees. The difference of soil type and compaction degrees affects the soil parameters, and thus affect soilstructure interaction. According to "Canadian Highway Bridge Design Code" [10], keeping remaining parameters unchanged, analysing four situations that elastic modulus values are $12 \mathrm{Mpa}, 15 \mathrm{MPa}, 24 \mathrm{MPa}$ and $30 \mathrm{MPa}$. Comparative analysis results are shown in Figs. (2 and $\mathbf{3})$.

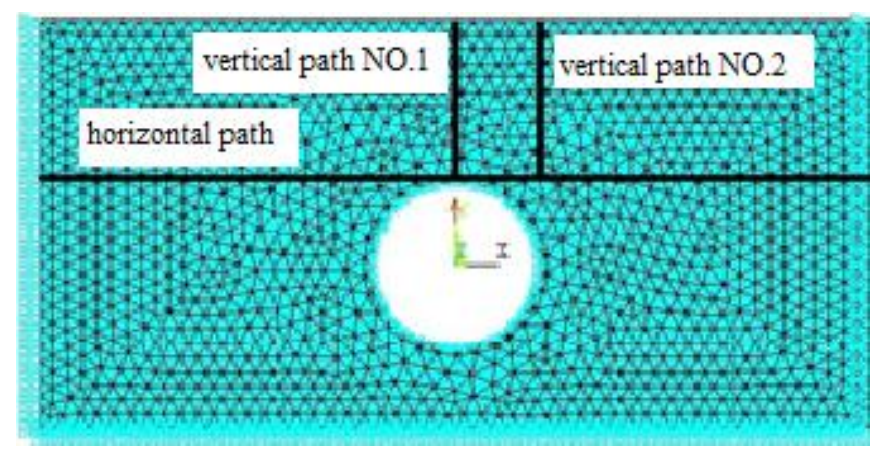

Fig. (1). Finite element model.

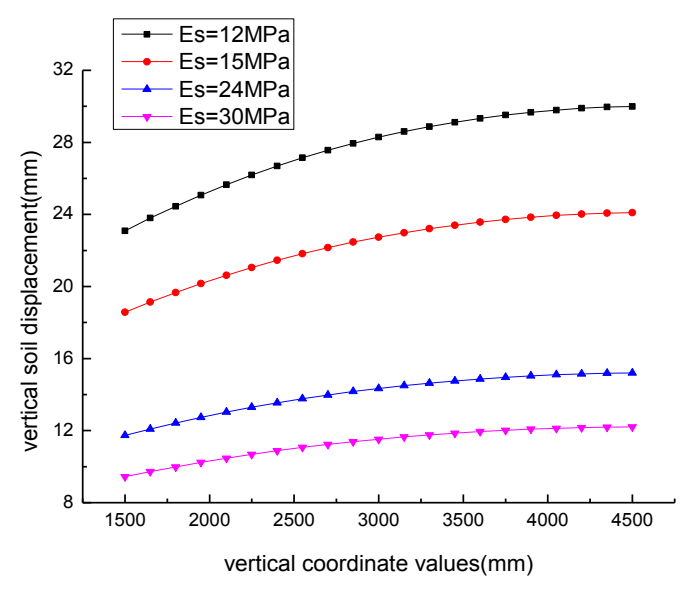

(a) Vertical path No. 1

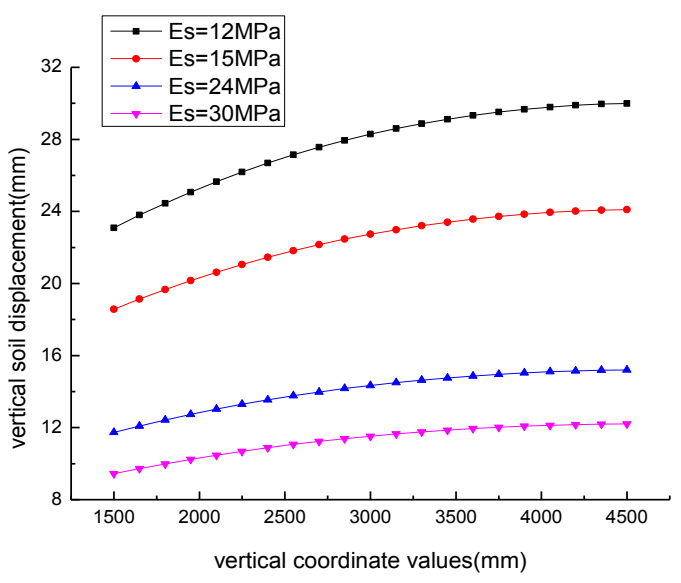

(b) Vertical path No. 2

Fig. (2). Soil displacements of vertical path under different soil elastic modulus. 


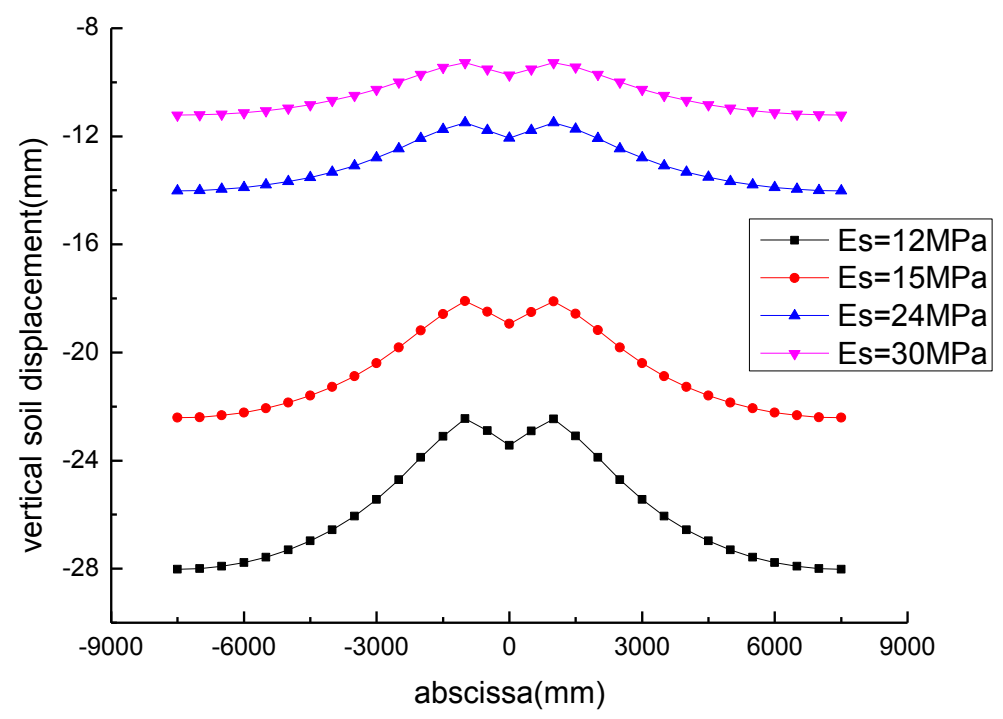

Fig. (3). Soil displacements of horizontal path under different soil elastic modulus.

As shown in Fig. (2), when other parameters are constant, at the same abscissa (depth) soil displacement value decreases with the increase of the elastic modulus. This is due to the elastic modulus which becomes large giving soil the ability that soil to resist external deformation increase, thus soil displacement becomes smaller. At the same elastic modulus, soil displacement value of vertical path NO.2 is larger than vertical path NO.1. For example, to the elastic modulus value of $24 \mathrm{MPa}$, at the position of $0.6 \mathrm{~m}$ above the pipe top, displacement value of vertical path NO.1 is $13.8 \mathrm{~mm}$ and NO.2 is $13.979 \mathrm{~mm}$, A difference of $1.28 \%$. Displacement of the side of pipe is greater than the displacement of the pipe top, which is due to stiffness of corrugated steel plate is large, the ability to resist soil deformation is stronger, therefore soil deformation of the soil prism directly above the structure is less than that of the adjacent soil prisms. Relative displacement of the pipe top soil and the side of pipe soil becomes large as the elastic modulus of the soil decreases.

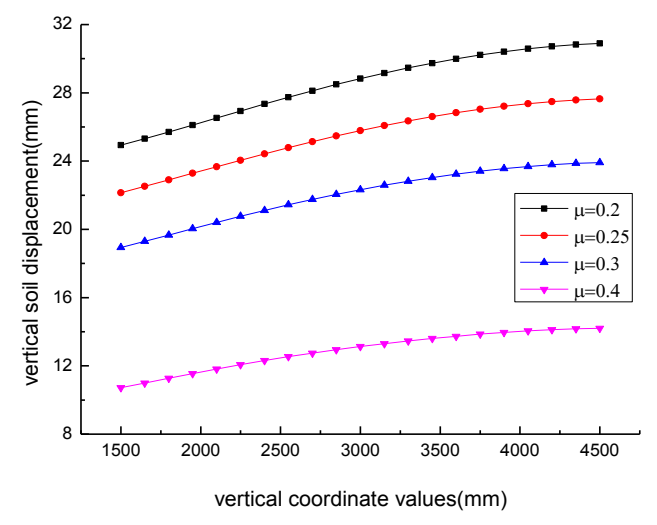

(a) Vertical path No. 1
As Fig. (3) shows, Displacement values of the soil prism directly above the structure are less than adjacent soil prisms, also performing the rigid pipe characteristics.

\section{SOIL POISSON'S RATIO}

Soil Poisson's ratio is the ratio of soil transverse strain and soil vertical strain, affecting the nature of the soil, thus affecting soil-structure interaction. Based on "Code for investigation of geotechnical engineering" [11], keeping other parameters unchanged, analyzing four situations that soil Poisson's ratio value are $0.2,0.25,0.3$ and 0.4 . Comparative analysis results are shown in Figs. (4 and 5).

As shown in Fig. (4), when other parameters are constant, soil displacement decreases with soil Poisson's ratio increases. The trend of vertical path NO.1 is similar to the vertical path No.2. As Poisson's ratio increases, the soil under the weight is more prone to lateral deformation, causing soil pressed against each other and lateral restraint enhance-

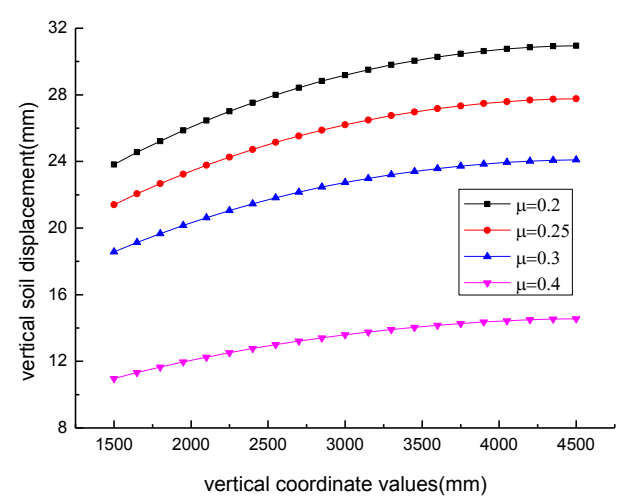

(b) Vertical path No. 2

Fig. (4). Soil displacements of vertical path under different soil Poisson's ratio. 


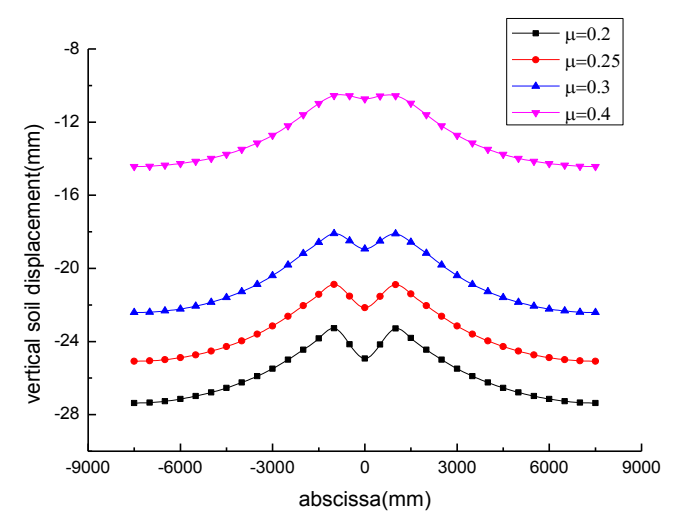

Fig. (5). Soil displacements of horizontal path under different soil Poisson's ratio.

ment. Hence, the soil vertical deformation is restrained and the displacement decreases.

As Fig. (5) shows, the displacement of the soil prism directly above the structure is less than that of the adjacent soil prisms, which affects the performance of the rigid pipe. When Poisson's ratio is small, the change of displacement is large for horizontal path and displacement value of the pipe top is larger than the side of pipe. However when Poisson's ratio increases, the soil lateral restraint enhances and deformation difference decreases.

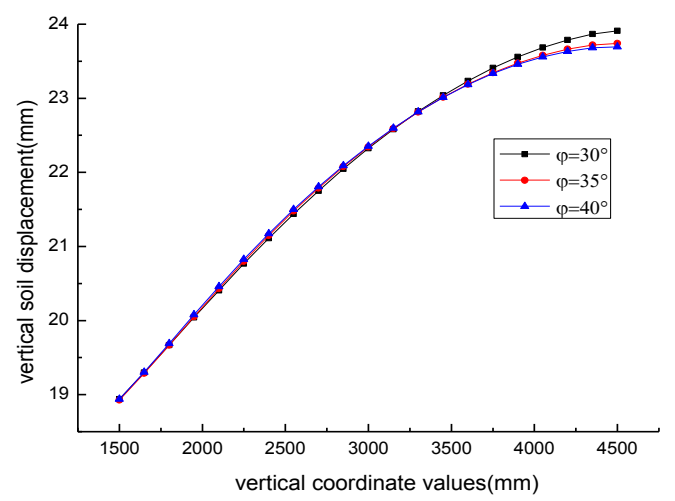

(a) Vertical path No. 1

\section{SOIL INTERNAL FRICTION ANGLE}

Based on "Specifications for Design of Highway Subgrades" [12], keeping the remaining parameters unchanged, analyzing three situations that soil internal friction angle values are $30^{\circ}, 35^{\circ}$ and $40^{\circ}$. Comparative analysis results are shown in Figs. (6 and 7).

As shown in Fig. (6 and 7), the range of soil internal friction angle is only $10^{\circ}$ which has little influence on the displacement in the vertical path and horizontal path. So the soil internal friction angle change has a little effect to the structure's rigid and flexible performance.

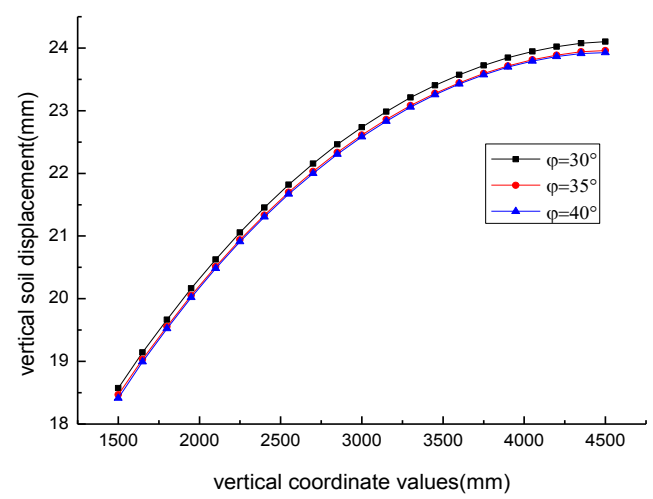

(b) Vertical path No. 2

Fig. (6). Soil displacements of vertical path under different soil internal friction angles.

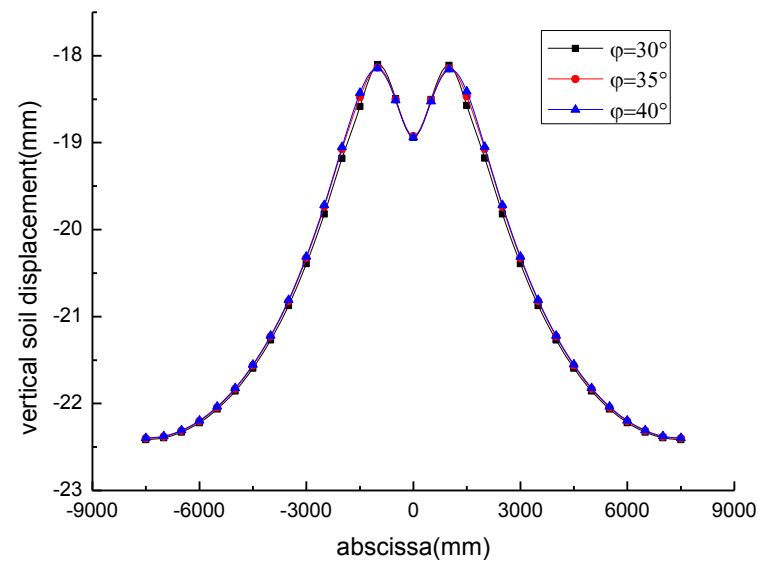

Fig. (7). Soil displacements of horizontal path under different soil internal friction angles. 


\section{CORRUGATED STEEL PLATE CROSS-SECTIONAL MOMENT OF INERTIA}

When simplify the corrugated steel plate to flat plate according to the equivalent stiffness principle. The size of the waveform will have a significant impact on the moment of inertia. According to the provision of "Corrugate sheet plate in highway bridges and culverts" [13], comparing the six waveforms in the specification. The profile of corrugated plate is shown in Fig. (8). The basic parameters of difference cross-section of the corrugated steel plate are shown in the Table 1.

The soil displacements along with two vertical path lines with the six different cross-sections of corrugated steel plate are shown in Fig. (9). Select the points of $0.6 \mathrm{~m}$ above the crown of the pipe at the two vertical path lines, the displacement distributions with the six different cross-sections of corrugated steel plate are shown in Fig. (10).

As is seen in Fig. (9), with the increase of corrugated steel plate inertia moment, the structure's rigidity increases and the ability to resist deformation structure is enhanced, soil displacement values become smaller of vertical path NO.1 and No.2. When inertia moment is small, soil displacement values show little change with inertia moment change.

As shown in Fig. (10), at the point ( $0.6 \mathrm{~m}$ to crown), with the increase of corrugated steel plate inertia moment, soil displacement values is decrease, and the change extent of vertical path NO.1 is larger than No.2. That is because the pipe affecting the soil on vertical path No.2 is smaller than the soil on vertical path No.1.
As shown in Fig. (11), the culvert inertia moment is larger, the displacement values are smaller within the span of the pipe culvert, but farther and farther away from the center of pipe culvert, showing the opposite trend. That is because with the increases of corrugated steel plate inertia moment, the structure's rigidity increases. The friction force of soil prism directly above the structure and the adjacent soil prisms are larger, which cause soil displacement decrease in.

\section{PIPE DIAMETERS}

Culvert diameters to a certain extent affect the rigidity of the pipe culvert. Keeping other parameters unchanged, analyzing three situations that diameter values are $1 \mathrm{~m}, 2 \mathrm{~m}$ and $3 \mathrm{~m}$. When analyzing the soil displacement of each path, to take an equal number of points to see its displacement distribution within the span of the pipe culvert. The soil displacement contrasts of three diameters on different paths are shown in Fig. (12 and 13).

As shown in Fig. (12), the larger diameter of pipe culvert, the larger values of soil displacement are. Close to the soil surface, soil displacement change trends become slowed. That is because with the increase of diameter, the structure's rigidity decreases, and the ability to resist deformation also decreases, soil displacement increases, pipe culverts closer to the flexible pipe. When close to the soil surface, the distance to pipe crown is large, the effect by changing the radius is small, and soil displacement trends become slowed.

As shown in Fig. (13), the difference of soil displacement values is not large on the range of culvert span. To $1 \mathrm{~m}$ pipe,

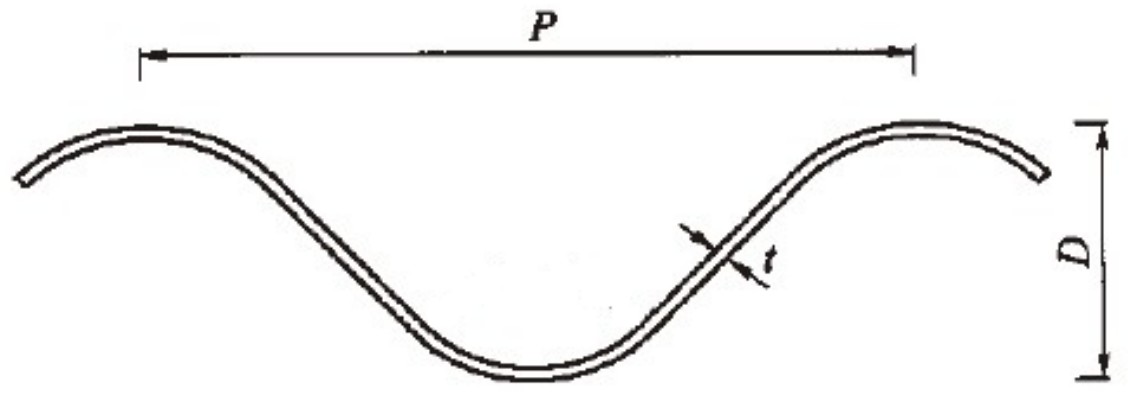

Fig. (8). Profile of corrugated steel plate.

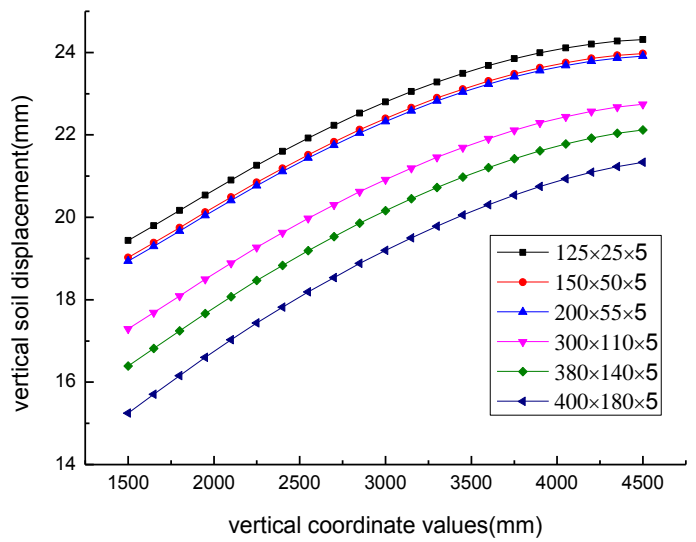

(a) Vertical path No. 1

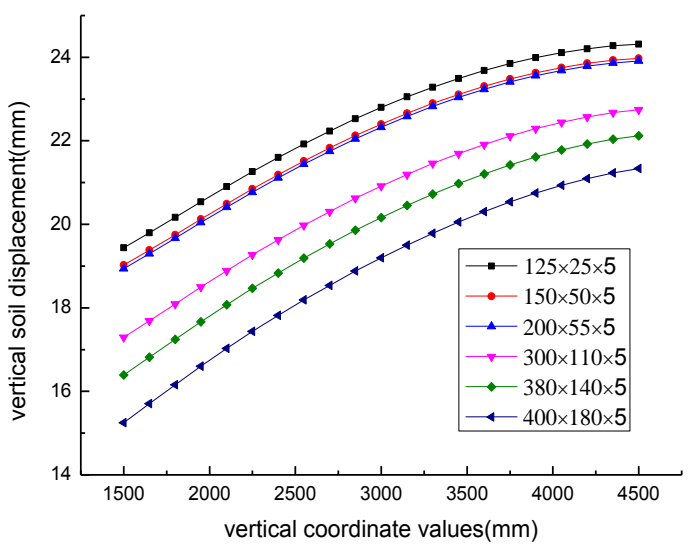

(b) Vertical path No. 2

Fig. (9). Soil displacements of vertical path under different moments of inertia. 
Table 1. Basic parameters of difference cross-section of corrugated steel plate

\begin{tabular}{|c|c|c|c|c|}
\hline \multirow{2}{*}{ Wave Number } & Wave Type & Thickness & Equivalent Area & Moment of Inertia \\
\cline { 2 - 5 } & $P \times D(\mathrm{~mm} \times \mathrm{mm})$ & $t(\mathrm{~mm})$ & $A_{P}\left(\mathrm{~mm}^{2} / \mathrm{mm}\right)$ & $I_{P}\left(\mathrm{~mm}{ }^{4} / \mathrm{mm}^{2}\right.$ \\
\hline \hline 1 & $125 \times 25$ & 5 & 5.462 & 409.051 \\
\hline 2 & $150 \times 50$ & 5 & 6.171 & 2053.489 \\
\hline 3 & $200 \times 55$ & 5 & 5.832 & 8664.905 \\
\hline 4 & $300 \times 110$ & 5 & 6.382 & 1454.27 \\
\hline 5 & $380 \times 140$ & 5 & 6.393 & 24485.854 \\
\hline 6 & $400 \times 180$ & 5 & 6.952 & \\
\hline
\end{tabular}

soil displacement distribution is of arch shape. To $3 \mathrm{~m}$ pipe, soil displacement distribution is of saddle-shape. The maximum displacement values are at the pipe crown.

\section{DISTINGUISH FORMULA OF RIGIDITY AND FLEXIBILITY FOR BURIED CORRUGATED STEEL PIPE CULVERT}

From the finite element analysis we can see that the elastic modulus, Poisson's ratio of the backfill soil, inertia mo- ment of corrugated steel plate and pipe diameter have a large effect on the displacements of the structure, that is to say that they have a large effect on the rigidity and flexibility of buried corrugated steel culvert. And soil internal friction angle has a small influence on the structure. Based on the positive or negative effects and the degree of the influenced of the above influence factors, we propose the distinguished formula of rigidity and flexibility for buried corrugated steel pipe culvert as follows:

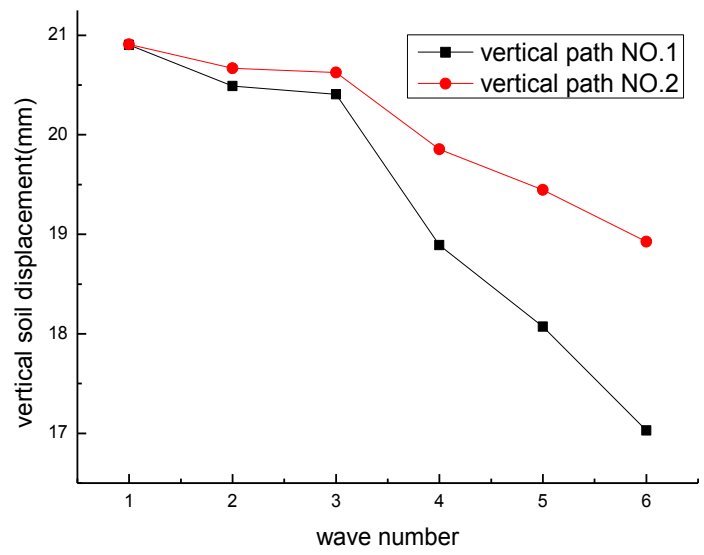

Fig. (10). Soil displacements of a point $(0.6 \mathrm{~m}$ to crown) with inertia moment increasing under the two vertical paths.

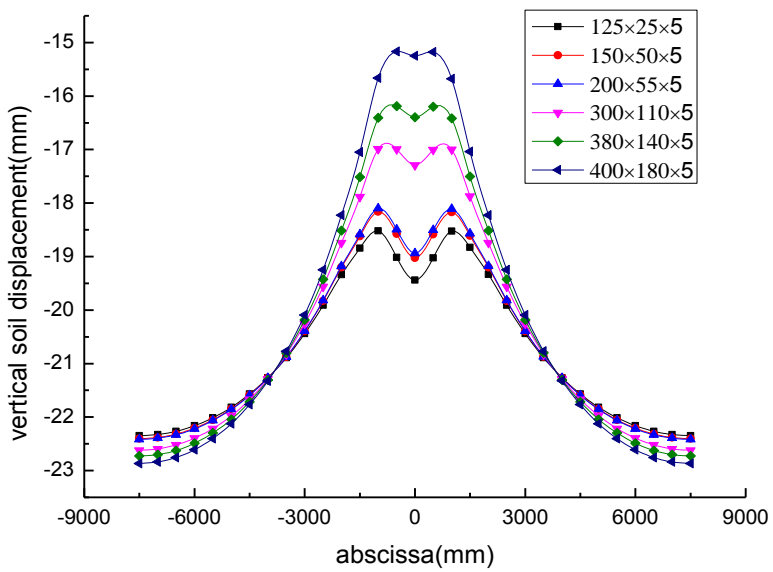

Fig. (11). Soil displacements of horizontal path under different moments of inertia. 


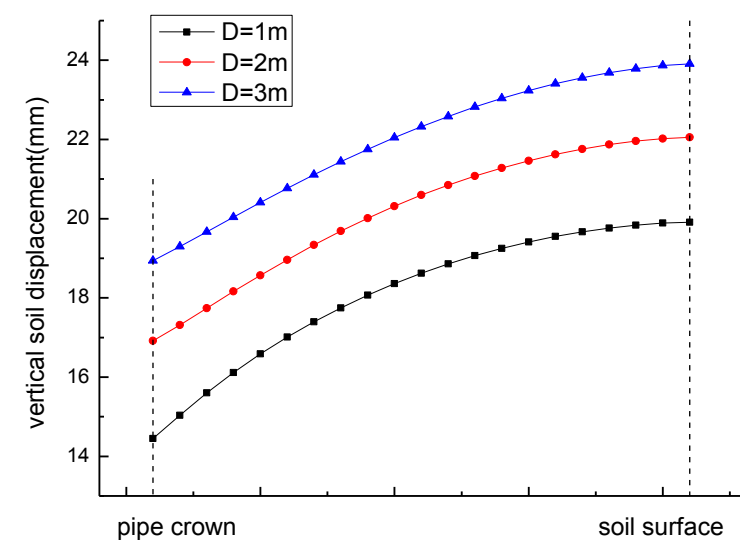

(a) Vertical path No. 1

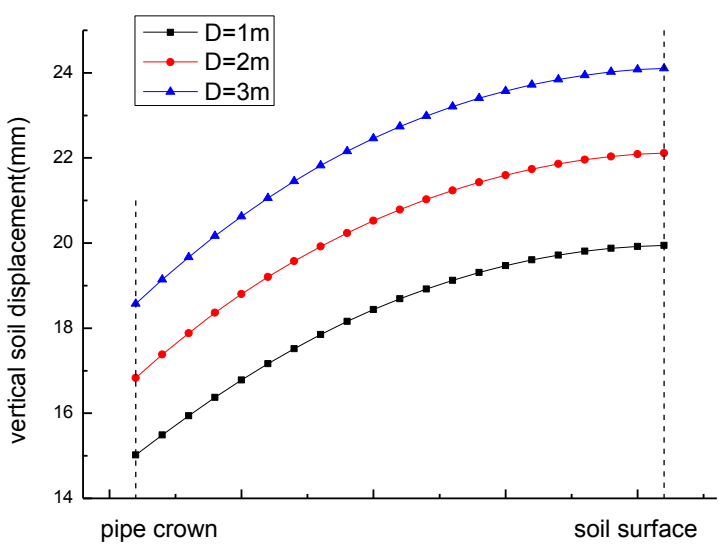

(b) Vertical path No. 2

Fig. (12). Soil displacements of vertical path under different pipe diameters.

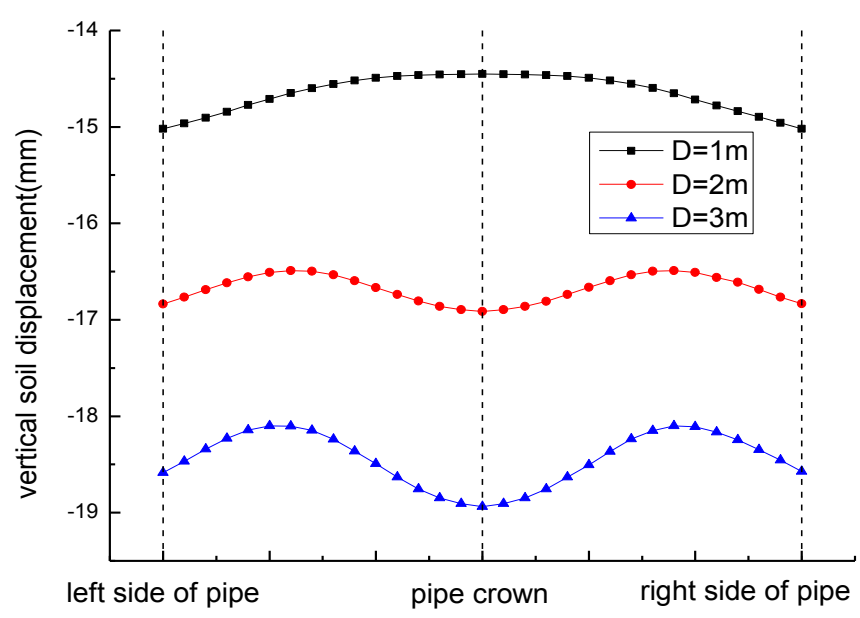

Fig. (13). Soil displacements of horizontal path under different pipe diameters.

Flexible pipe:

$R F F=\frac{E_{p}}{E_{s}} \cdot \frac{I_{p}(1+\mu)(1-2 \mu)}{D^{2} A_{p} \tan \varphi}<1$

Rigid pipe:

$R F F=\frac{E_{p}}{E_{s}} \cdot \frac{I_{p}(1+\mu)(1-2 \mu)}{D^{2} A_{p} \tan \varphi} \geq 1$

Where $R F F$ is relative stiffness parameters; $E_{p}$ is elastic modulus of structure $(\mathrm{MPa}) ; E_{s}$ is elastic modulus of soil $(\mathrm{MPa}) ; I_{p}$ is steel inertia moment of per unit length $\left(\mathrm{mm}^{4} /\right.$ $\mathrm{mm}) ; A_{p}$ is steel cross-sectional area of per unit length $\left(\mathrm{mm}^{2} / \mathrm{mm}\right) ; D$ is pipe diameter $(\mathrm{mm}) ; \varphi$ is internal friction angle of soil $\left(^{\circ}\right) ; \mu$ is Poisson's ratio of soil.

From the formula (1) and (2), change of the elastic modulus, Poisson's ratio, inertia moment of corrugated steel plate and pipe diameter have a large effect on the value of RFF. But the soil internal friction angles have a small influence, tangent function has been used to represent the effect of soil internal friction angle to the value of RFF. That is similar to the finite element analysis result.
A lot of corrugated steel culvert structure had been built in China. To list a few actual pipe culvert works as follows: (1) a corrugated pipe culvert had been built at the position of K3263+094 in the Qinghai-Tibet Highway in September 1998. The culvert design diameter is $1.5 \mathrm{~m}$, design thickness is $3 \mathrm{~mm}$, wave height is $7 \mathrm{~cm}$, wave pitch is $14 \mathrm{~cm}$, pipe culvert foundation used sand for filling and the thickness is 1.0$1.2 \mathrm{~m}$ [14]. (2) two corrugated pipe culvert had been built in Linzhao highway in June 2001. One pipe design diameter is $1.0 \mathrm{~m}$, wave pitch is $68 \mathrm{~mm}$, thickness is $2.5 \mathrm{~mm}$. the other design aperture is $1.5 \mathrm{~m}$, wave pitch is $200 \mathrm{~mm}$, thickness is $2.5 \mathrm{~mm}$ [15] (3). Considering the route importance and geological complexity changing the original $4 \mathrm{~m}$ diameter concrete pipe culvert to $2 \mathrm{~m}$ corrugated steel pipe culverts in 2009 Zhang Shi freeway, and the culvert size is $150 \mathrm{~mm} \times$ $68 \mathrm{~mm} \times 3.5 \mathrm{~mm}[16]$. (4) two corrugated pipe culverts had been built in Qinghai-Tibet Highway 2001, diameters are $1.5 \mathrm{~m}$ and $1.2 \mathrm{~m}$, the soil Poisson's ratio is 0.3 , the steel for the Q235 steel and elastic modulus take 200GPa. Using the waveform with size $140 \mathrm{~mm} \times 70 \mathrm{~mm} \times 4 \mathrm{~mm}$ and the thickness of the upper filling $4.6 \mathrm{~m}$ and $2.7 \mathrm{~m}$ [17]. (5) two corrugated pipe culverts had been built in Inner Mongolia. The steel for Q235, soil Poisson's ratio is 0.3 and elastic modulus take $200 \mathrm{GPa}$. The former uses waveform of $150 \mathrm{~mm} \times 72 \mathrm{~mm}$ $\times 3.5 \mathrm{~mm}$ size, diameter is $2 \mathrm{~m}$; latter uses waveform of 
Table 2. Rigid and flexible formula results of practical engineering.

\begin{tabular}{|c|c|c|c|c|c|c|c|c|c|}
\hline Number & $\begin{array}{c}\text { Corrugated } \\
\text { Size/ } \\
\mathbf{m} \times \mathbf{m m} \times \mathbf{m m}\end{array}$ & Diameter/mm & $\mathbf{C}$ & $\mathbf{F}$ & Stiffness[8] & RFF & Stiffness & FF & Stiffness[6] \\
\hline \hline 1 & $140 \times 70 \times 3$ & 1500 & 0.023 & 1.713 & Semi-rigid & 2.87 & rigid & 0.0008 & flexible \\
\hline 2 & $68 \times 13 \times 2.5$ & 1000 & 0.025 & 21.17 & flexible & 0.25 & flexible & 0.0017 & flexible \\
\hline 3 & $200 \times 55 \times 2.5$ & 1500 & 0.036 & 3.835 & Semi-rigid & 1.93 & rigid & 0.0005 & flexible \\
\hline 4 & $150 \times 68 \times 3.5$ & 2000 & 0.028 & 3.807 & Semi-rigid & 1.55 & rigid & 0.0005 & flexible \\
\hline 5 & $140 \times 70 \times 4$ & 1500 & 0.018 & 1.323 & Semi-rigid & 2.79 & rigid & 0.0020 & flexible \\
\hline 6 & $140 \times 70 \times 4$ & 1200 & 0.014 & 0.677 & rigid & 4.36 & rigid & 0.0039 & flexible \\
\hline 7 & $150 \times 72 \times 3.5$ & 2000 & 0.028 & 3.436 & Semi-rigid & 1.67 & rigid & 0.0005 & flexible \\
\hline 8 & $150 \times 72 \times 3.5$ & 1500 & 0.025 & 1.691 & Semi-rigid & 2.97 & rigid & 0.0008 & flexible \\
\hline 9 & $200 \times 55 \times 3.5$ & 1200 & 0.020 & 1.402 & Semi-rigid & 3.02 & rigid & 0.0027 & flexible \\
\hline 10 & $125 \times 25 \times 1.6$ & 1200 & 0.048 & 15.40 & flexible & 0.64 & flexible & 0.0002 & flexible \\
\hline 11 & $200 \times 55 \times 6$ & 4107 & 0.055 & 49.62 & flexible & 0.21 & flexible & 0.0002 & flexible \\
\hline
\end{tabular}

$150 \mathrm{~mm} \times 72 \mathrm{~mm} \times 3 \mathrm{~mm}$ size, diameter is $1.5 \mathrm{~m}$; two pipe culverts corresponding filling height of $6.29 \mathrm{~m}$ and $6.74 \mathrm{~m}$ respectively [18]. (6) two model test pipes were built in HengShui He Bei province. The waveform having the size $200 \mathrm{~mm} \times 55 \mathrm{~mm} \times 3.5 \mathrm{~mm}$ and $125 \mathrm{~mm} \times 25 \mathrm{~mm} \times 1.6 \mathrm{~mm}$, diameter is $1.2 \mathrm{~m} \mathrm{[19].} \mathrm{(7)} \mathrm{Fang} \mathrm{Yafei} \mathrm{in} \mathrm{the} \mathrm{literature} \mathrm{[20]} \mathrm{men-}$ tioned in the actual project uses a waveform $200 \mathrm{~mm} \times 55 \mathrm{~mm}$ $\times 6 \mathrm{~mm}$, diameter $4.107 \mathrm{~m}$ pipe culvert.

Comparing formula from literature $[6,8]$ and the formula given in this paper suggest to rigid flexible calculation, results are shown in Table 2.

As shown in Table $\mathbf{2}$, the rigidity and flexibility division method given in this paper are similar to the literature [8] and quiet difference from the literature [6]. Showing the suggested formula is reasonable and the division formula for reinforced concrete pipe in the code of China is not suitable for corrugated pipe culvert. The proposed formula given in this paper is particularly for buried corrugated steel pipe culverts, divided it into two types of rigid pipe and flexible pipe. Relatively speaking, more targeted and specifically and provides computing reference for these structure's rigidity and flexibility analysis.

\section{CONCLUSION}

According to the analysis of the rigidity and flexibility of the buried corrugated steel pipe culvert, educe the following conclusions:

(1) The soil vertical displacement above the pipe top decreases with the elastic modulus and Poisson's ratio increases. The structure is increasingly showing the mechanical properties of flexible pipe. And the soil internal friction angle has a small influence to the rigidity and flexibility of buried corrugated steel culvert.

(2) The soil vertical displacement above the pipe top de- creases with the cross-sectional moment of inertia increases. The structure is increasingly showing the mechanical properties of rigid pipe. The cross-sectional moment influence to the soil prism directly above the structure is greater than that of the adjacent soil prisms.

(3) The soil displacement increases with the increase in pipe diameter. The structure is increasingly showing the mechanical properties of flexible pipe.

(4) Elastic modulus, Poisson's ratio, inertia moment of corrugated steel plate and pipe diameter has a large effect on the structure's rigidity and flexibility. And the soil internal friction angle has a small influence to it.

(5) Distinguished formula for flexible and rigid pipes of the buried corrugated steel pipe culvert structure has been made according to the analysis results. The formula is proved reasonable according to the distinguish results of some practice engineering.

\section{CONFLICT OF INTEREST}

The authors confirm that this article content has no conflicts of interest.

\section{ACKNOWLEDGEMENTS}

This research was supported by National Nature Science Foundation of China (50878016) and the Technology Project of Inner Mongolia Transportation Department (NJ-2010-17).

\section{REFERENCES}

[1] G. Abdel-Sayed, B. Bakht, L. G. Jaeger. Soil-Steel Bridges Design \& Construction. New York: McGraw-Hill, 1993.

[2] Z. M. Feng. Soil-Structure Interaction Analysis and Design Method Study of Buried Corrugated Steel Bridges (In Chinese). Beijing: Beijing Jiaotong University, 2009.

[3] J. Kang, F. Parker, C. H. Yoo, "Soil-structure Interaction for Deeply Buried Corrugated Steel Pipes Part I: Embankment Installation”, 
Eng. Struct., Vol. 30, No. 2, pp. 384-392, 2008.

[4] S. A. Trickey, I. D. Moore, "Three-dimensional Response of Buried Pipes Under Circular Surface Loading", J. Geotech. Geoenviron. Eng.@ ASCE, pp. 219-223, 2007.

[5] Q.L Lin, M.Yang, "Study of Vertical Soil Pressure on Positive Buried Pipeline" (In Chinese)", Rock Soil Mech., vol. 22, no. 2, pp. 214-218, 2001.

[6] TG/T D66-04-2007. "Guidelines for Design of Highway Culvert" [S] (In Chinese). Beijing :China Communications Press. 2007.

[7] GB 50332-2002. "Structural Design Code for Pipelines of Water Supply and Waste Water Engineering" [S] (In Chinese). Beijing: China Architecture \& Building Press, 2002.

[8] I. D. Moore, "Buried Pipes and Culverts", Geotech. Geoenviron. Eng. Handbook, pp. 541-567, 2000.

[9] Q. L. Wang, B. D. Liu, Y. Z. Li, "Rigidity of Buried Corrugated Steel Pipe Culvert and its Influence to Mechanical Behaviors" J. Beijing Jiaotong University, vol. 36, no. 4, pp. 1-4, 2012.

[10] CAN/CSA-S6-00. "Canadian Highway Bridge Design Code" [S]. CSA International, Toronto, Ontario, Canada, 2000.

[11] GB 50021-2001. "Code for Investigation of Geotechnical Engineering" [S] (In Chinese). Beijing: China Architecture \& Building Press. 2001.

[12] JTG D30-2004. "Specifications for Design of Highway Subgrades" [S] (In Chinese). Beijing: China Communications Press. 2004.

[13] JT/T 710-2008. "Corrugate Sheet Plate in Highway Bridges and
Culverts" [S] (In Chinese). Beijing: China Communications Press. 2008.

[14] W. G. Zhao, Z. L. Li, C. J. Li, "Corrugated Steel Culvert Highway Research and Application Prospects" (In Chinese), Highway and Transport. Res. Appl. Techno. Ed. no. 8, pp. 166-170, 2007.

[15] Y. S. Bai, W. Gao, H. F. Li, "Application Research of Corrugated Steel Pipe Culvert in Highway Engineering" (In Chinese), Forest Eng., no. 3, pp. 28-30, 2008.

[16] J. Wang, Q. Liu, "Application of Corrugated Steel Pipe Culverts in Mountainous Freeway" (In Chinese), J. China \& Foreign Highway, no. 4, pp. 165-168, 2009.

[17] W. Y. Ji, Corrugated Metal Pipe Culverts Force Behavior Theory Analysis and Experimental Study (In Chinese), Beijing: Beijing Jiaotong University, 2004.

[18] X. M. Jiang, Experimental and Calculate Studies of Highway Corrugated Steel Pipe Culvert and Arch Culvert (In Chinese), Beijing: Beijing Jiaotong University, 2005.

[19] Z. Wang, Comparative Experiment and Study on Rigidity and Flexibility of Buried Corrugate Steel Pipe Culverts (In Chinese), Beijing: Beijing Jiaotong University, 2013.

[20] Y. F. Fang, X. Wen, "Finite Element Analysis of Embedded Steel Corrugated Pipe Structure" (In Chinese), Urban Roads Bridges \& Flood Control, no. 6, pp. 120-123, 2007.

Received: October 16, 2013

Revised: January 07, 2014

Accepted: January 07, 2014

(C) Liu et al.; Licensee Bentham Open.

This is an open access article licensed under the terms of the Creative Commons Attribution Non-Commercial License (http://creativecommons.org/licenses/ by-nc/3.0/) which permits unrestricted, non-commercial use, distribution and reproduction in any medium, provided the work is properly cited. 